\section{特 集 $\square$ 最近の送信技術}

い. この場合，コントロールパネルを放送機用ラックに 取付け，そこから監視制御を行っている.

\section{3. 主 要 機 器}

\section{1 配電盤}

配電盤は，高電圧を JEM-1153，低圧盤を JEM-1265 に基づく閉鎖形とし, キャビネットを鋼板構造として地 震発生時における加速度の応答倍率を小さくして, 配電 盤内の電気部品や母線に与える影響を少なくしている。

（注） JEM：日本電機工業会標準規格

\section{2 遮断器}

遮断器は, 性能, 信頼度の面から真空遮断器を使用し ている. 真空遮断器は完全自己消弧方式のため進展故障 の遮断ができ，アークエネルギーも少ないため接点の開 閉寿命が長い. また, 保守省力形遮断器なので運転コス トむ少ないなどの特徴を備えている.

\section{3 変圧器}

変圧器には, 油入式と乾式（含モールド形）がある. コストの面では前者の方が安価であるが，防災の面では 後者の方が優れている.

特に最近では，火災に対しての安全性が強調されるた め, 乾式やモールド変圧器が採用される場合が多い.

\section{4 電圧調整器}

電圧調整器は誘導形が大半である. 変圧器同様, 油入 式と乾式があるが，容量の大きなむの（100 kVA 以上） については乾式の製作が困難である.

現在は, 制御回路は静止化されているが, 今後, 本体 むサイリスタ素子を使用した静止形とし，より高性能， 高信頼度のものが採用されると思われる。

\section{5 保護継電器}

保護継電器には誘導形と静止形がある. 一般には前者 が多く使用されているが，特に耐震を考慮し，地震中に あ運転を継続する必要のある設備については静止形を使
用するのが望ましい.

\section{4. 保 護 方 式}

前記のように，機器のみを高性能化しても保護系統が しっかりしていなければ信頼度の高い設備とはいえな い. その意味で, バックアップむ含めて確実な保護協調 をとり，万が一の事故時にむ，すみやかにその回路を切 り離し波及事故を最小限にくい止めねばならない。 ま た，停電時には確実に非常系統に切り換える必要があ る.

これらを迅速，かつ正確に行うむのとして静止形の継 電器ユニットが製品化されている，乙れは，各継電器の 要素を用途別に 1つのケースにま之めたむので，例え ば，高圧の受電保護継電装置では，“過電流要素”, “地 絡方向要素”, “逆相, 不足電圧要素”, “過電圧要素”な ごから構成されている，さらに，自動点検機能を有して いるため, 全継電要素の動作および復帰点検を自動的に 行うことができる．また，回路が二重化されているた め，点検中に実事故があった場合でむ，事故に対応した 出力を出すことができる.

\section{5.むす び}

放送用電源として安定した電源を供給するためには高 性能の機器を使用することが必要である。 また, 設備系 統を二重化し信頼度を向上させることも必要である.

さらに, 防災の面から, 耐震, 防火を考慮し, 静止形 継電器の導入や機器のオイルレス化なども検討すべきで ある。

なお，制御回路にマイクロコンピューターを使用する 方法む現在検討されており, 今後, 放送用電源はますま す信頼度を向上させる方向にいくものと思われる.

(昭和 55 年 12 月 11 日受付)

\title{
4-2 非常用自家発電装置
}

\section{1. まえ がき}

非常用電源設備には, 自家発電設備, 専用受電設備,

\section{$\dagger$ 西芝電機株式会社技術部}

"4-2 Standby Generator Set for Emergency Service" by Masami Fujita (Engineering Department, Nishishiba Electric Co., Ltd., Tokyo)
藤田誠已†

蓄電池設備の 3 種類があるが, 負荷に対する適応性, 電 源容量の大きさ, 独立した電源であること, などの点か ら，自家発電設備が最む適切であるといえる.

非常用自家発電装置の計画には, 所要容量の決定, 原 動機の選定, 電力系統, 制御方式, 付帯設備の選択と配 置の検討など種々の技術的要因があるが，ここでは主と して原動機の選定, 最近の発電機, 電力系統と制御方 
式，高調波対策などについて紹介する.

\section{2. 構 成}

非常用自家発電装置は, 次の機器により構成される. 交流発電機 ( 3 相交流同期発電機) 原動機（ディーゼル機関またはガスタービン） 発電機盤（自動始動装置を含む） 補機器類（燃料系統, 冷却水系統, 始動系統) 直流電源装置（制御用，始動用）

\section{3. 原動機の選定}

非常用自家発電装置の発電機駆動用の原動機には, 一 般にディーゼル機関とガスタービンが多く採用されてい る.乙れらを比較すると，表1の通りであるが，両者に は一長一短があり，一概にいずれが優れているかは断言 できない，始動特性, 冷却水の有無, 燃料の種類, 建屋 と据付面積の制限などの条件を考慮して, 総合的な判断 を要する.

\section{4. 発電機の特徵}

最近の発電機の特徴をあげると, 次の通りである.

\section{1 ブラシレス励磁方式である}

励磁方式には，交流励磁機によるブラシレス方式と, 静止励磁装置による自励式の 2 種類があるが, 信頼性の 向上と保守点検の容易さからブラシレス方式が多い.

\section{2 絶縁種別は $\mathbf{F}$ 種である}

電機子巻線, 界磁巻線の絶縁種別は, 従来のB種より も優れた $\mathrm{F}$ 種絶縁が多くなってきている.

\section{3 電圧変動特性が良い}

漸変電圧変動率は, 原動機の速度変動率を $5 \%$ とした ときでも大体 $\pm 1.5 \%$ 以内となっている.

瞬時電圧変動率は, 発電機定格電流の $100 \%$ に相当す る負荷を突然加えたとき一般には $30 \%$ 以内であるが， 要求により $20 \%$ 以内に抑えるてとむ可能である.

\section{5. 電力系統と制御方式}

\section{1 電力系統}

非常用自家発電装置は，一般には常用電源之並 列運転は行わず, 受電側遮断器と発電機側遮断器 との間には, 電気的または機械的インターロック を設ける必要がある. 受電および負荷回路の系 統, 遮断器・開閉器の適用, 母線の配置などによ り電源切換の方式は異なるが，高圧回路の一例を 図 1 亿示す.

\section{2 原動機の制御系統}

原動機の始動方式には，セルモーターによる方
表 1 原動機による発電装置の此較 (500 kW の場合)

\begin{tabular}{|c|c|c|}
\hline & ディーゼル機関 & ガスタービン \\
\hline 機 器 重 量 & $300 \%$ & $100 \%$ \\
\hline 機 器 寸 法 & $150 \sim 200 \%$ & $100 \%$ \\
\hline 燃 料 油 & 軽油, 重油 & 軽油, 灯油, ガス \\
\hline 燃 料 消 費 量 & $100 \%$ & $180 \sim 230 \%$ \\
\hline 熱 効 率 & $35 \%$ & $20 \%$ \\
\hline 冷 却 水 & $\begin{array}{l}\text { クーリングタワー方 } \\
\text { 式で約 } 0.8 \mathrm{t} / \mathrm{h} \text { 必要 }\end{array}$ & 不 要 \\
\hline 潤滑油消費量 & $100 \%$ & $1 \sim 10 \%$ \\
\hline 礎 & $\begin{array}{r}\text { 必要な地耐力 } \\
6 \sim 8 \mathrm{t}\end{array}$ & $\begin{array}{l}\text { 機器重量を支えるだ } \\
\text { けの基礎 }\end{array}$ \\
\hline $\begin{array}{l}\text { 基礎コンクリー } \\
\text { 卜荷重 }\end{array}$ & $\begin{array}{l}\text { 機器重量に対して, } \\
\text { 固定式 } 5 \text { 倍 } \\
\text { 防振式 } 1.5 \sim 2 \text { 倍 }\end{array}$ & $\begin{array}{r}\text { 機器重量に対して } \\
1.1 \sim 1.2 \text { 倍 }\end{array}$ \\
\hline 屋 & $\begin{array}{l}\text { 比較的大きく補機の } \\
\text { 㞜付用スペースが必 } \\
\text { 要 }\end{array}$ & 小さく簡易にできる \\
\hline $\begin{array}{l}\text { 特 性 } \\
\text { 始 動 時間 } \\
\text { 速度变動率 }\end{array}$ & $\begin{array}{l}\text { 短い (10 20 秒) } \\
8 \sim 10 \%\end{array}$ & $\begin{array}{l}\text { 長い }(40 \sim 60 \text { 秒) } \\
5 \sim 10 \% \text { (1 } 1 \text { 軸式) } \\
25 \sim 35 \% \text { (2 軸式) }\end{array}$ \\
\hline 出 & $\begin{array}{l}\text { 周囲温度による影響 } \\
\text { は小さ. }\end{array}$ & $\begin{array}{l}\text { 周胭温度により大き } \\
\text { 影響され. }\end{array}$ \\
\hline $\begin{array}{cr}\text { 価 } & \text { 格 } \\
\text { 機 } & \text { 器 } \\
\text { 総 建 } & \text { 設 } \\
\text { 費 }\end{array}$ & $\begin{array}{l}\text { 安 } \\
\text { 高 }\end{array}$ & $\begin{array}{l}\text { 高 } \\
\text { 安 }\end{array}$ \\
\hline
\end{tabular}

法と圧縮空気による方法がある。いずれの場合あ商用電 源の停電時には，シーケンス制御により原動機を自動始 動させる. 一例として, 図 2 亿空気始動式ディーゼル機 関の系統図, 図了に始動時のタイムスケジュールを示 す.

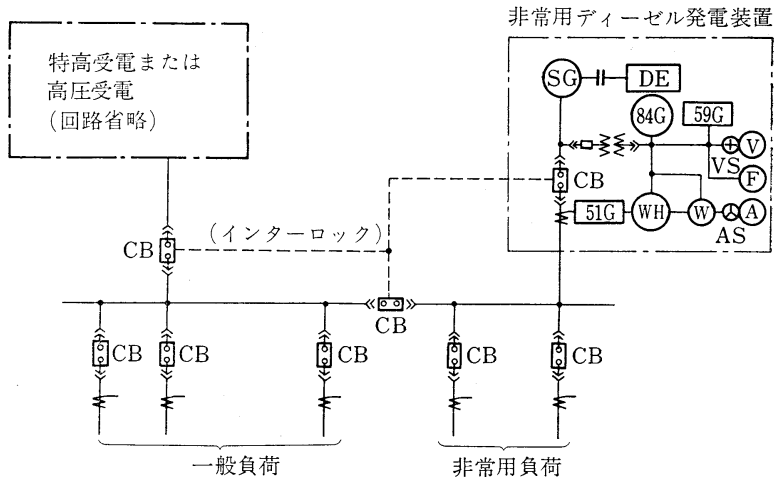

図 1 高圧主回路の切換回路例 


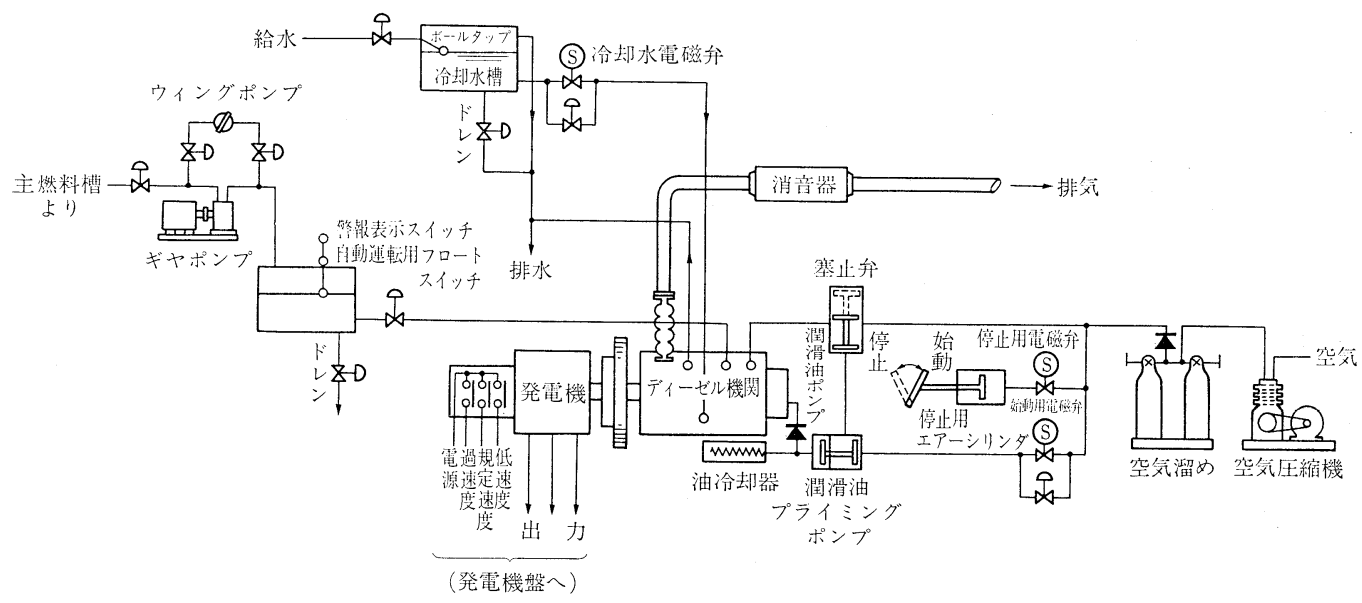

図 2 空気始動式ディーゼル発電設備の系統

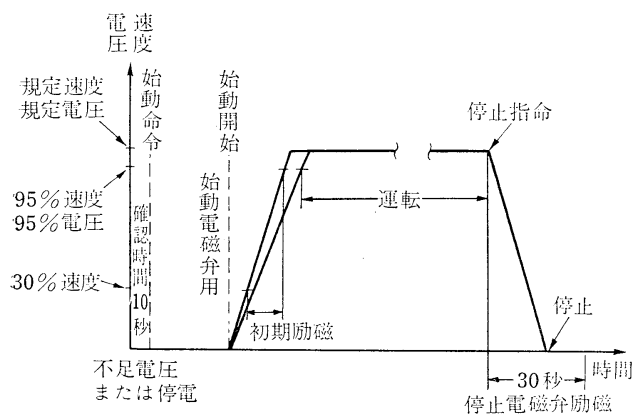

図 3 タイムスケジュール

\section{6. 高調波電流の影響1}

\section{1 発電機に与える影響}

静止形 CVCF のようなサイリスタ負荷がある場合, 接続された発電機に高調波電流が流入することにより， 次の悪影響を及ぼす。

（1）ダンパ巻線内の温度の増加（各高調波電流がダ ンパ巻線内に流れ， $I^{2} R$ 損失が増加する)

（2）固定子巻線の温度上昇の増加（表皮効果は周波 数の 2 乗で増加するため巻線の損失が増える)
（3）固定子鉄損の増加（鉄損中のヒステリシス損は 周波数に比例し，うず電流損は周波数の 2 乗に比 例するため，鉄損は増加する)

さらに，高調波電流による電圧波形のひずみは，誘導 障害の原因にもなる。

\section{2 等価逆相電流}

サイリスタ負荷の場合，6 倍，12 倍……高調波電流 が発生するため，乙れらを等価逆相電流に換算して，通 常の逆相電流と同一レベルにして取扱う.

等価逆相電流とは，高調波電流による損失と逆相電流 による損失が等しいとして算出するもので次式による.

$$
\begin{aligned}
I_{2 e q}=\sqrt{\sum_{\nu}\left(\sqrt[4]{\frac{\nu}{2}} \cdot I_{\nu}\right)^{2}} \\
\text { ただし, } I_{2 e q}: \text { 等価逆相電流 } \\
\nu: \text { の倍数 } \\
I_{\nu}: \text { 高調波電流 }
\end{aligned}
$$

通常，乙の值は発電機定格電流の $15 \%$ 以内とする必 要がある。

(昭和 55 年 12 月 11 日受付)

$$
\text { 〔参考文 献〕 }
$$

1) 高橋満：高調波電流負荷（整流器負荷など）の同期機に 及ぼす影響，電学誌，93，6 (1973) 491-498 